\title{
A VASOACTIVE POLYPEPTIDE EXTRACTED FROM CALLORHINUS MUSCLES, AND ITS CLINICAL APPLICATION
}

\author{
TAKASHI HAYASHI,* TOSHIRO OTSUKA, SADAO AIKAWA \\ and HIROSHI HOSHINO \\ Department of Physiology, School of Medicine, \\ Keio University, Tokyo, Japan
}

(Received for publication December 12, 1966)

We name it callopeptide, which is extracted from muscles and viscera of fur seal (callorhinus ursinus), because it is a polypeptide, according to an agreement now generally accepted ${ }^{8,} 12$ that peptide-like compounds of 3-90 amino acids are called polypeptide, of which the upper limit corresponds to a molecular weight of approximately 10,000 and the ability to pass through cerophane membranes,

Table 1

Classification of Functional Polypeptides

\begin{tabular}{|c|c|c|c|c|}
\hline & Classification & Examples & Amino acids & Function \\
\hline 1. & Tissue hormones & $\begin{array}{l}\text { 1) Angiotensins } \\
\text { 2) Bradykinins } \\
\text { 3) Substance P } \\
\text { 4) Gastrin }\end{array}$ & $\begin{array}{c}8 \\
9 \\
\text { unknown } \\
17\end{array}$ & $\begin{array}{l}\text { hypertensive } \\
\text { hypotensive } \\
\quad \text { "f } \\
\text { secretory }\end{array}$ \\
\hline 2. & $\begin{array}{l}\text { Glandular } \\
\text { hormones }\end{array}$ & $\begin{array}{ll}\text { 1) Pituitary } & \text { ACTH } \\
\text { Oxytocin } \\
\text { 2) Pancreas } \\
\text { Insulin } \\
& =\text { Glucagon }\end{array}$ & $\begin{array}{r}39 \\
9 \\
51 \\
31\end{array}$ & $\begin{array}{l}\text { secretory } \\
\quad \prime \prime \\
\text { glycolytic } \\
\quad / 1\end{array}$ \\
\hline 3. & Neurohormnes & $\begin{array}{l}\text { 1) Corticotropin releasing } \\
\text { factor } \\
\text { 2) Luteinizing hormone } \\
\text { releassing factor }\end{array}$ & $\begin{array}{c}12 \\
\text { unknown }\end{array}$ & $\begin{array}{c}\text { secretory } \\
\| \prime\end{array}$ \\
\hline 4. & Antibiotics & $\begin{array}{l}\text { 1) Actinomycins } \\
\text { 2) Gramicidins }\end{array}$ & $\begin{array}{l}12 \text { with a Rest } \\
10 \text { cyclic }\end{array}$ & $\begin{array}{l}\text { sterilizing } \\
\quad /\end{array}$ \\
\hline
\end{tabular}

* Emeritus professor of Physiology. 
separates polypeptides from proteins.

The structure elucidation and pharmacological evaluation of biologically active polypeptides have greatly advanced in the course of the recent 10 years $^{9,11}$ as shown in Table 1 which is edited from the standpoint of physiology. Callopeptide belongs to a category of the tissue hormones in the table, according to its biological actions, especially among which to the hypotensive polypeptide group.

The hypotensive peptides hitherto discovered are summarized in Table 2. Their origins are various, for example, bradykinin is formed during active secretion in salivary glands, sweat glands, and exocrine portion of the pancreas, and it increases the blood flow in these tissues. Eledoisin is presumed to be the same. Other kinins are found in wasp and other insects venoms, they are not normal occuring but probably can be released in vivo. Substance $U$ and $\mathrm{Z}$ must be also metabolite in vivo owing to the fact that they are found in normal urine. These hitherto-known active polypeptides are all metabolite in vivo, but callopeptide is not a metabolite, it is an artificially extracted polypeptide by a certain procedure from the skeletal and visceral muscles of a special marine animal. ${ }^{10}$

Table 2

Hypotensive Polypeptides and Their Origins

\begin{tabular}{|c|c|c|c|c|}
\hline Name & $\begin{array}{c}\text { Amino } \\
\text { acids }\end{array}$ & Origin & Extraction & Authors \\
\hline 1. Bradykinin & 8 & human plasma & $\begin{array}{l}\text { trypsin ethanol } \\
\text { extraction }\end{array}$ & $\begin{array}{l}1947 \text { Rocha e } \\
\text { Silvea }\end{array}$ \\
\hline 2. Substance $P$ & unknown & $\begin{array}{l}\text { Equine intestine } \\
\text { and brain }\end{array}$ & $\begin{array}{l}\text { alcoholic } \\
\text { extraction }\end{array}$ & $\begin{array}{l}1931 \text { von Euler } \\
\text { and Gaddum }\end{array}$ \\
\hline 3. Eledoisin & 11 & $\begin{array}{l}\text { Salivary glands } \\
\text { of Cephalopoda }\end{array}$ & $\begin{array}{l}\text { methanol } \\
\text { extraction }\end{array}$ & 1954 Erspamer (4) \\
\hline 4. Wasp-kinin & unknowu & Wasp venom & $\begin{array}{l}\text { diethyl ether } \\
\text { extraction }\end{array}$ & $\begin{array}{l}1954 \text { Jacques } \\
\text { and Schachter }\end{array}$ \\
\hline 5. Hornet-kinin & $\prime \prime$ & Hornet venom & $\prime \prime$ & $\begin{array}{l}1960 \text { Bhoola Calle } \\
\text { and Schachter }(2)\end{array}$ \\
\hline 6. Substance U & $\prime \prime$ & Urine & $\begin{array}{l}\text { alcoholic } \\
\text { extraction }\end{array}$ & 1952 Belaldo (1) \\
\hline 7. Substance $\mathrm{Z}$ & $\prime \prime$ & $\prime \prime$ & $\prime \prime$ & $\begin{array}{l}1960 \text { Werle } \\
\text { and Erdös }\end{array}$ \\
\hline 8. Colostrokinin & $" \prime$ & Bovine colostrum & $\begin{array}{l}\text { hydrochloric acid, } \\
\text { ethanol extrac- } \\
\text { tion }\end{array}$ & 1960 Werle \\
\hline 9. Pysalaemin & 11 & Amphibian skin & $\begin{array}{l}\text { methanol } \\
\text { extraction }\end{array}$ & $\begin{array}{l}1962 \text { Erspamer, } \\
\text { Bertaccini and } \\
\text { Cei }\end{array}$ \\
\hline 10. Callopeptide & unknown & $\begin{array}{l}\text { Callorhinus } \\
\text { muscles }\end{array}$ & $\begin{array}{l}\text { protease, } 60-80 \% \\
\text { alcoholic } \\
\text { extraction }\end{array}$ & $\begin{array}{l}\text { 1963-1966 } \\
\text { Hayashi et al }\end{array}$ \\
\hline
\end{tabular}


In order to determine whether this new polypeptide which has biological activity is present in other mammals, experiments were conducted on extracts prepared by the same method as used in preparing the callopeptide, using as the material animals, dog, cat, cow, hog and whale, common seal, dolphine, but the presence of an active ingredient could not be found. This result should be sufficient to assume that the callopeptide is a substance which is singulary possessed by the aquatic animals of the family otariidae. In other words, the existence of the substance in fur seal is quite akin to natural occurence.

\section{Extraction Method}

The callopeptide is obtained by a method consisting of the steps (a) $+(b)$, the step (a) being that in which at least one of either the skeletal muscles or viscera of a fur seal, an animal of the family otariidae, is decomposed and the step (b) being that in which the resulting decomposition liquid is extracted with a water-containing organic solvent, the water-containing organic solventsoluble portion being collected.

Table 3

Extraction Method*

1. Schredded, elimination of oils and fats mechanically and by hydrophobic solvent.

2. Protease, adding toluene to prevent microbes- 4 hours.

3. Hydrochloric acid is added as to $10.8 \%-70^{\circ} \mathrm{C} 1$ hour.

4. Neutralized, precipitates are removed by centrifuging, and barium hydroxide is added as to $4 \mathrm{~N}$. $-65^{\circ} \mathrm{C} 1$ hour.

5. Neutralized by sulfric acid and preciptates are removed.

6. Boiled to inactivate the enzyme, and odorous substances are removed by steam distillation.

7. Concentrated under reduced pressure at a temperature as low as possible and ethanol is added until $60-80 \%$ by weight in $80-90^{\circ} \mathrm{C}$.

8. Filtration and collection of ethanol-soluble portion.

9. Vacuum and spray drying, -an amorphous powder. (The erude product.)

* The industrial use of the method is covered by patents both in U.S.A., U.K. and other countries.

As shown in Table 3, in carrying out this decomposing step (a), first the material should preferably be shredded and eliminated oils and fats into a slurry state having fluidity by adding water in a suitable amount. Second when the decomposing is to be carried out by means of the enzymatic decomposition, a protease is utilized for several hours.

When the optimum pH of said protease is close to that of the material flesh, 
it is used without adjustment, but if it is on the acid side, the $\mathrm{pH}$ of the material slurry is adjusted by adding a physiologically harmless weak acid.

The aforesaid decomposing step (a) can also be carried out by subjecting the material slurry to hydrolysis. Usually hydrochloric acid is added to a slurry of the material flesh in an amount such that the total hydrochloric acid concentration become $10-20 \%$, the hydrolysis then being carried out for from several ten minutes to several hours, with stirring while maintaining a temperature of $30-80^{\circ} \mathrm{C}$. After the decomposition, the liquid is neutralized by adding caustic soda, following which the precipitate is removed by centrifuging.

Then in carrying out the extraction step (b) the following procedure is followed. The decomposition liquid is boiled to inactivate the enzyme followed by filtering off the solid matter and, the remaining organic solvent and odorous substances are then removed from the decomposition liquid usually by means of steam distillation. The solution is then concentrated under reduced pressure at a temperature as low as possible, after which ethanol is added to the concentrated liquid, if necessary, with the addition of water, until the concentration of said ethanol in the liquid after addition of the solvent becomes $60-80 \%$ by weight. The liquid is then heated under reflux preferably at $80-90^{\circ} \mathrm{C}$. to effect the full dissolution of the soluble portion in said organic solvent, following which filtration is carried out to collect the ethanol-soluble portion.

The treatment of collecting the water-containing extraction solvent-soluble portion may be repeated. When the resulting extraction solvent solution is dried utilizing evaporation, vacuum and spray drying or other known drying techniques, an amorphous powder containing the callopeptide in high concentration is ob-

Table 4

Physical Properties

1. Soluble in

(1) water

(2) water-containing ethanol (not more than $80 \%$ )

(3) methanol, butanol

(4) acetone (water-containing at least 20\%)

Insoluble in

(1) alcohols of above $80 \%$

(2) acetone of above $80 \%$

2. Dialysable through cerophane membrane. (The inside liquid losts physiological actions.)

3. Molecular weight

(1) positive Biuret reaction indicates that it is greater than tripeptide.

(2) Swedberg unit is not more than 1.0 , estimating as being $\mathbf{S}_{20}$, hence $M . W$. is not greater than 10.000 . 
Table 5

Chemical and Biological Properties

1. Amount of free amino acids was negligible.

2. The number of unknown peaks of Abderhalden-Schmidt reaction was 10-12.

3. Hydrolysis; peaks disappear and amino acids, roughly estimated, appear as following; glycine, alanine, valine, leucine, isoleucine, proline, threonine, lysine, aspartic acid, and glutamic acid.

- $\mathrm{LD}_{50}$ of callopeptide via peritoneal injection

$$
\begin{aligned}
& \mathrm{CP}=14.4 \mathrm{~g} / \mathrm{kg} \\
& \mathrm{PP}=7.7 \mathrm{~g} / \mathrm{kg}
\end{aligned} \quad \text { (mouse and rat) }
$$

tained, which we named the crude product (SP). The crude product has the following physical and chemical properties as shown in Table 4 and 5.

(1) Solubility: Soluble at room temperature in water and water-containing ethanol (not more than $80 \%$ ethanol). Soluble at room temperature in methanol, butanol and acetone (containing in all cases at least $20 \%$ of water). Isoluble in alcohol and acetone of above $80 \%$ concentration.

(2) Biuret reaction: The biuret reaction to be hereinafter defined is positive. The maximum absorption of the color resulting from the biuret reaction is at $550 \mathrm{~m} \mu$. In this connection that in the case of native peptide is $545 \mathrm{~m} \mu$.

(3) Estimation of molecular weight: A cellophane tube is filled with $100 \mathrm{ml}$ of a water-contained alcohol solution containing about $10 \mathrm{mg}$ of peptide per $1 \mathrm{ml}$ of the solution, following which dialysis is carried out with water for 24 hours at $20^{\circ} \mathrm{C}$. From the fact that the inside liquid of the dialysis, when tested for its physiological activity, had lost its activity, it is not conceivable that said peptide is a polypeptide having 10 or more amino acids linked thereto. That the biuret reaction is positive indicates that it is tripeptide or greater. An aqueous solution containing about $8 \mathrm{mg}$ of peptide per $1 \mathrm{ml}$ of the solution is ultracentrifuged at $60,000 \mathrm{rpm}$ for one hour. When the resulting schlieren pattern is observed, the sedimentation constant in terms of Swedberg units is estimated as being $\mathbf{S}_{20}$ (sedimentation constant at $20^{\circ} \mathrm{C}$ ) of not more than 1.0 , and hence it is estimated that the molecular weight is not greater than 10,000 .

(4) Tyrosine residue: The optical density at $220-230 \mathrm{~m}_{\mu}$ at which is seen the absorption of the tyrosine residue of a $0.005 \pm 0.001 \%$ by weight aqueous solution of the substance is substantially zero.

(5) Amino acids: When the substance is tested with the amino acid automatic analyzer, the amount of free amino acids is very slight, and number of unknown peaks which develop color by reacting with ninhydrine (Aberder- 
halden-Schmidt reaction) are observed to be 10-12 or even more. When the callopeptide is subjected to hydrolysis and then again tested with the amino acid automatic analyzer, these peaks disappear and practically all classes of amino acids appear.

\section{The Purification}

In order to further purification, the crude product in ethyl alcohol solution is concentrated under reduced pressure to eliminate the alcóhol as well as to concentrate the original solution to a volume $1 / 100-1 / 50$ of that of the original volume, following which the solution is passed through a column of cross-linking dextran for example, "Sephadex" G-10, G-25 and G-50 (products of SwedenPharmacia Company) those with the smaller G-number being the finer and the biuret reaction positive portion is collected.

In carrying out this treatment, the upper end of a column packed with "Sephadex" G-25 (fine) is filled with the previously described concentrated liquid, after which it is flowed down through the column using distilled water. An outflow rate of about $25-75 \mathrm{ml}$ per hour is suitable. When, for instance, $5 \mathrm{ml}$ portions of the liquid are fractionated. A biuret reagent is added to the liquid and the optical density of the color developed is measured at a wavelength of $550 \mathrm{~m} \mu$. At the same time the optical density shown by the tyrosine residue at a wavelength of $270-280 \mathrm{~m} \mu$ is also measured.

When this is illustrated with reference to Fig. 1, the optical density at the wavelength of $550 \mathrm{~m}_{\mu}$ is indicated on the vertical axis at the left, while the optical dendity at the wavelength of $270 \mathrm{~m} \mu$ is indicated on the vertical axis at the right. On the other hand, the horizontal axis shows the volume of the liquid

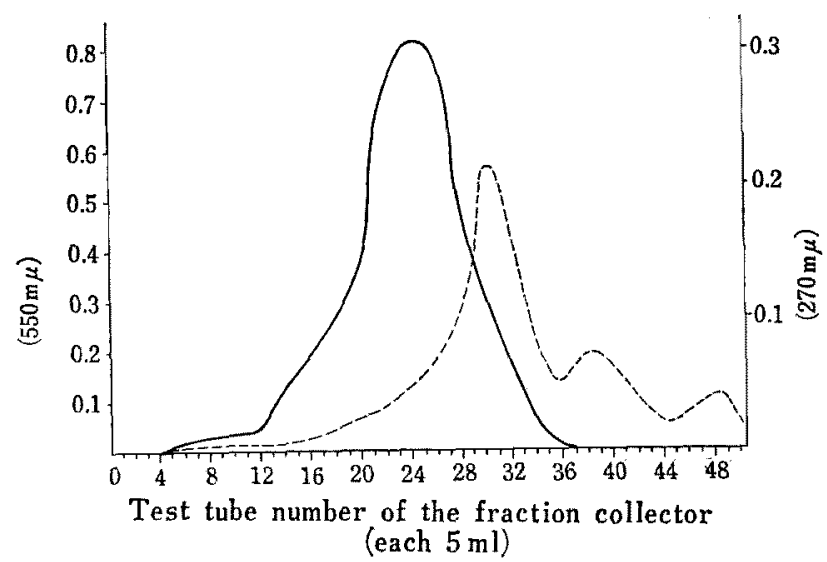

Fig. 1 Fractioned portions and their optical densities at $550 \mathrm{~m} \mu$ and $270 \mathrm{~m} \mu$ wavelength. 
which has flowed out, the numerals being the test tube number of fraction collector, each of which has a capacity of $5 \mathrm{ml}$. The curve shown by means of the solid line is the optical density curve of the instance when the specimen was measured at the wavelength of $550 \mathrm{~m} \mu$, while that shown by means of the dotted line is the optical density of the instance when the specimen was measured at the wavelength of $270 \mathrm{~m} \mu$. The ranges in which test tubes Nos. 1-12, 13-28, $29-35,36-44$ and $45-50$ fall are considered to be respectively the first, second, third, fourth and fifth fractional portions.

The optical density of both curves appear intensely in the second and third fractional portions, the indication of biuret reaction positive being especially pronounced. When the physiological activity of the several fractional portions are investigated, they are as follows: A strong capillary vasodilator activity was noted in the case of the second and third fractional portion (purified product $\mathrm{PP}$ ). It could not be confirmed in case of the portions other than the second and third fractional portions. From the fact the components of this second fractional portion especially shows an intense biuret reaction, it is presumed that it contains polypeptides of tripeptide and above. Further, when components of this portion are examined with the amino acid automatic analyzer, the free amino acids are observed in very minute amounts, but there are seen 10-12, or more, unknown peaks which develop color by reacting with ninhydrine. Next, when this portion is subjected to hydrolysis and again examined with the amino acid automatic analyzer, these unknown peaks disappear, and practically about 10 amino acids appear, as shown in Table 5. From these results, it is presumed that there is present together in the second fractional portion a number of classes of polypeptides, but these 10 amino acids combined one will be most concentrated.

As one of the other purification means, there is a method wherein an ion exchange resin is used. In this case, the aqueous solution from which has been evaporated under reduced pressure the solvent of the water-containing extraction solvent solution, or an aqueous solution of the crude product which has once been made into a powder is eluted with an acid buffer using a column of an ion exchange resin such, for example, as "Dowex" 50 or "Amberlite" 50, following which the effluent is collected and concentrated to a given concentration.

\section{Actions of Callopeptide on the Brain of Mammals}

To study the biological action of callopeptide, we first determined the lethal dose for mice or rats, by the peritoneal injection. The lethal dose, LD 50, was $14.4 \mathrm{~g} / \mathrm{kg}$ in the crude product and $7.9 \mathrm{~g} / \mathrm{kg}$ in the purified one, as shown in Table 5. In later experiments, we used 1-2 $\mathrm{mg}$ of $1.0 \%$ solution for cat and rabbit, 1-2 $\mathrm{mg}$ of $2.0 \%$ solution for dogs. 
Table 6

EEG and Evoked Potential

1. EEG in dogs-no change for 2 hours when $2 \mathrm{ml} / \mathrm{kg}$ of $1.0 \%$ of the crude callopeptide (C.P.) solution was given through peritoneal injection.

2. Evoked potential of cats-10-17\% enhancement, $30-135 \mathrm{~min}$ after the peritoneal injection of $2 \mathrm{ml} / \mathrm{kg}$ of $1.0 \%$ crude callopeptide solution.

3. Dilatation of surface blood vessels of exposed cortex of dogs after the peritoneal injection of $2 \mathrm{ml} / \mathrm{kg}$ of $1.0 \%$ callopeptide. When the preparation was for $4-5$ hours surgically manipulated one, the dilatation accompanied a diffuse bleeding to a slight oozing extent.

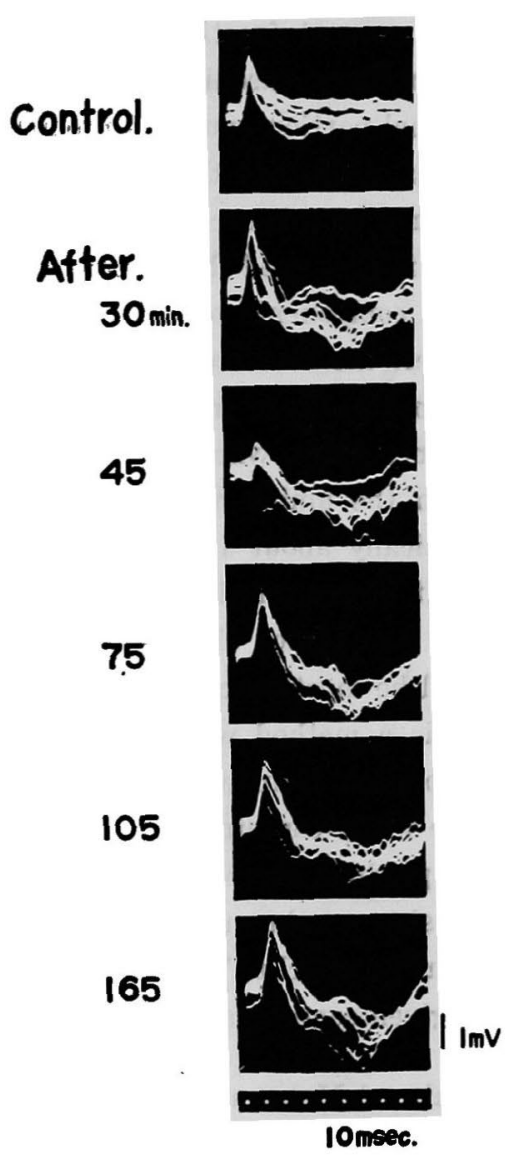

Fig. 2 The evoked potentials of the cortex of a cat, before and after the callopeptide injection.

\section{Control.}

\section{After. \\ 30 min.}

105
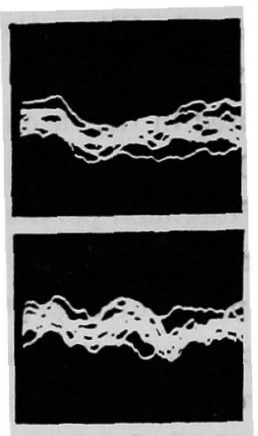

150
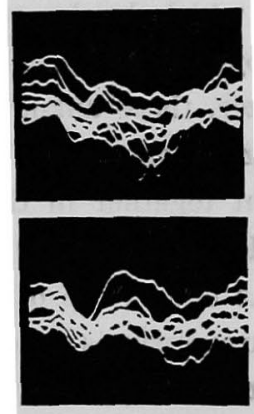

180

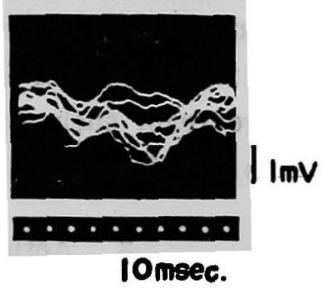

Fig. 3 The membrane potentials of the ipsilateral somatic sensary cortex of the cat, before and after the callopeptide injection. 
The first experiment was to try the measuring EEG of dogs when callopeptide of $2 \mathrm{ml} / \mathrm{kg}$ of $1.0 \%$ of the crude product solution was given by peritoneal injection. As Table 6, the cortical EEG has shown no change for 2 hours after the injection.

The second experiment was to measure the evoked potential of cortical cells in dogs. A microelectrode was applied on the somatic sensory area of dogs and its evoked potential was measured by the electrical stimulation to the excised ischiadicus nerve. Fig. 2 showed the evoked potentials when callopeptide was injected intravenously. The potential measured at the contralateral somatic sensory cortex was increased $15-17 \%$ of height as shown in Fig. 2. On the contrary the ipsilateral somatic sensory area has not shown the evoked potential, of course, before the injection as in Fig. 3, nor after it.

Not only the evoked potential was augmented the surface blood vessels of the cerebral cortex were distinctly dilated by naked eye obsevation, and most significant phenomenon was the diffuse bleeding from the surface vessels of cerebral cortex in the preparation which was undergone through a long surgical manipulation.

Thus we have obtained three notices.

1. An augmentation of the evoked potential with a latent period of $\mathbf{2 0 - 4 0}$ min after intravenous injection of callopeptide, and it continued for hours.

2. Dilatation of peripheral vessels.

3. Permeability of general capillary walls increased.

Table 7

Action of Callopeptide upon Cortical Cells

1. Enhancement of evoked potential (see Fig. 2 and 3)

2. Dilatation of peripheral blood vessels,

3. Permeability of capillary walls increase. For example a diffuse bleeding after a lapse of long surgical manipulation.

Does the enhancement of evoked potential of the cortical cells come from

1) Stimulatory action of callopeptide, or

2) The dilatation of cortical blood vessels?

\begin{tabular}{cccc}
\hline Dog & \multicolumn{2}{c}{$\begin{array}{c}\text { Callopeptide into csf } \\
\text { (each 5 min) }\end{array}$} & $\begin{array}{c}\text { Motor action } \\
\text { (Seizure) }\end{array}$ \\
\hline male 10.0 kg & $10 \%$ solution & $0.5 \mathrm{ml}$ & $(-)$ \\
& $\prime \prime$ & $0.5 "$ & $(-)$ \\
& $" \prime$ & $0.5 "$ & $(-)$ \\
& $\prime \prime$ & $1.0 "$ & $(-)$ \\
& $" 1.0 "$ & $(-)$ & $(-)$ no further change. \\
\end{tabular}


Does the augmentation of the evoked potential come from (1) stimulatory action of callopeptide on cortical cells or (2) from the dilatation of cortical blood vessels? To solve the question, we made an experiment to introduce the substance into cerebrospinal fluid of dog. If the substance has a stimulatory action, when we introduce the substance excessively into c.s.f. of the animal it must excite the motor cortex and produce seizure. Table 7 showed the experiment that the motor phenomenon could not be obtained when $5.0 \mathrm{ml}$ of $10 \%$ of callopeptide solution was introduced. Moreover, when we applied the solution on the exposed cortical surface, it did not excite the cells. Thus the augmentation of the evoked potential of cortex, presumed to be owed to the dilatation of cortical vessels, not to the stimulatory action of the substance.

As histamine is vasodilatory substance, we compared the action of the dilatation on cats cortical vessels of callopeptide and histamine. Table 8 showed the results. Callopeptide was effective when it was given as to the concentration of $0.000143 \%$ in cats body, the congestion of cortical surface was obtained, and vascular permeability increased, but in histamine when its concentration was attained to $0.00089-0.0089 \%$ the same dilatation was obtained, and it was over than the lethal dose for the cat.

Table 8

Callopeptide and Histamine upon Cortial Vascular System

\begin{tabular}{|c|c|c|}
\hline Items & Callopeptide & Histamine \\
\hline Animal & Cat $(2.5 \mathrm{~kg})$ & Cat $(2.5 \mathrm{~kg})$ \\
\hline Dose of peritoneal injection & $1 \mathrm{ml}$ of $0.358 \% \mathrm{CP}$ & $1 \mathrm{ml}$ of $0.2-2.0 \mathrm{M}$ \\
\hline Calculated concentration & $0.000143 \%$ & $0.00089 \%-0.00889 \%$ \\
\hline Congestion & + & + \\
\hline $\begin{array}{l}\text { Diffuse bleeding } \\
\text { (after a long surgical manipulation } \\
\text { on the exposed corotex) }\end{array}$ & + & - \\
\hline End effect & alive & dead \\
\hline
\end{tabular}

4. Vasodilatory and Hypotensive Aetion of Callopeptide

Vasodilatory action of callopeptide was experimented i) to examine the mesenterial blood vessels by abdominal window method in rabbits, and ii) to observe the vascular beds of rabbit's retina by taking colored pictures before and after the intravenous injection of $2 \mathrm{ml} / \mathrm{kg}$ of $1.0 \%$ callopeptide solution.

An example of retinal funduscopy is shown in Fig. 4, A, B, C and D. Fig. 4A was a control picture before the injection and $B$ the one hour later when $0.9 \mathrm{ml} / \mathrm{kg}$ 
of $2.0 \%$ callopeptide solution was intravenously injected. Comparing the colors of both fundus pictures, the vasodilating action of callopeptide can be recognized by naked eye.

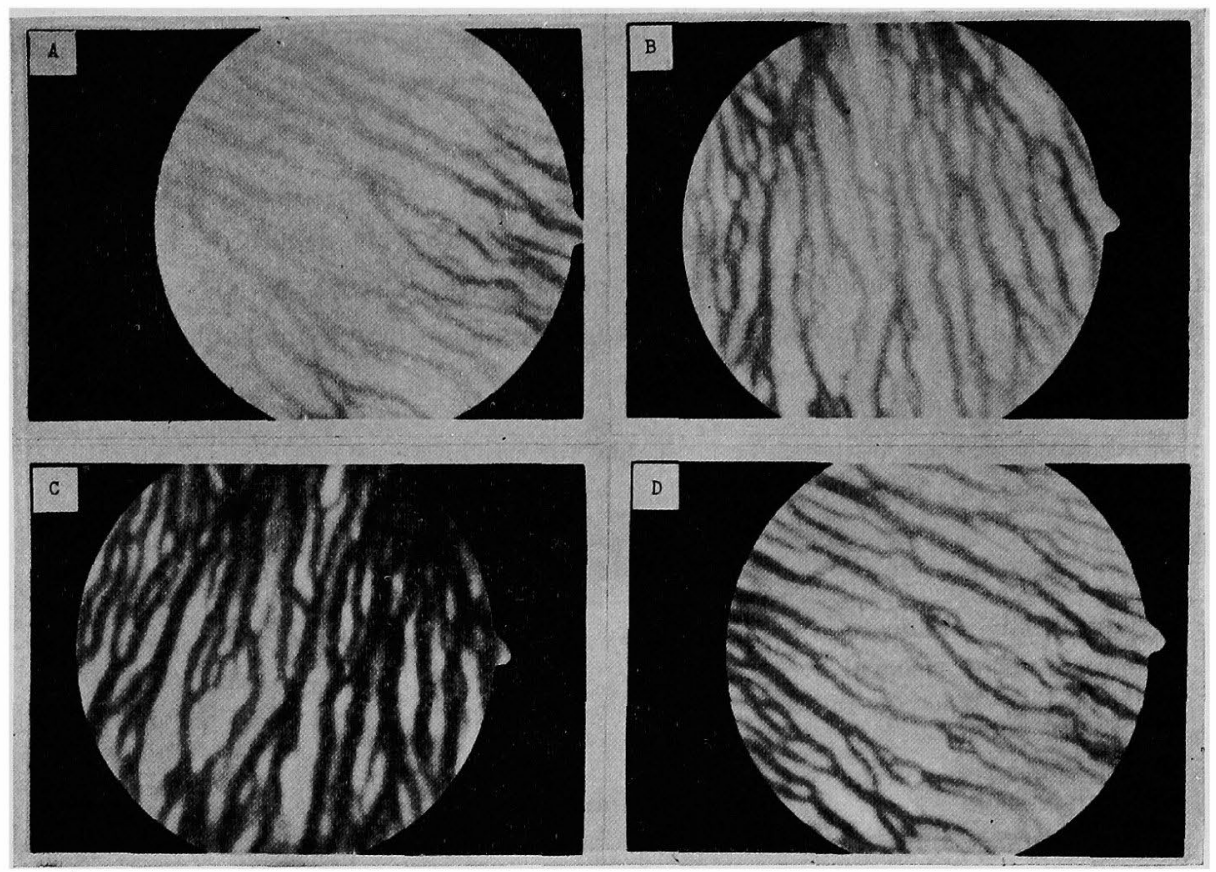

Fig. 4 Pictures of retinal funduscopy of a rabbit. Rabbit $2.8 \mathrm{~kg}$. A: before the injection, B: $60 \mathrm{~min}, \mathrm{C}: 120 \mathrm{~min}$, and D: $180 \mathrm{~min}$ after the injection of $0.9 \mathrm{ml}$ of $2.0 \%$ callopeptide solution.

From our studies, callopeptide has a strong vasodilatatory action in cortical surface, mesentery and retinal fundus. Generally speaking, the peripheral vessels of the whole body should be dilated by callopeptide. Necessarily it must result the blood pressure lowering. Then, hypotensive action of callopeptide was examined by the measuring of blood pressure of A. femoralis by inserting a cannula into the left femoral artery of a rabbit. The normal pressure was $150-160 \mathrm{mmHg}$ in 2.5-3.5 $\mathrm{kg}$ weighed rabbits, and when $2 \mathrm{ml} / \mathrm{kg}$ of $1.0 \%$ callopeptide solution was given intravenously, the pressure was lowered about $20 \mathrm{mmHg}$ with a latent period of 30-40 min as shown in Table 9. There was an upper limit of the effect of callopeptide, for example, when the callopeptide was given 5-7 mI/ kg of the above solution, the pressure could not be lowered more than $25 \mathrm{mmHg}$. 
Table 9

Vasodilatory and Hypotensive Action of Callopeptide

1. The vasculer beds of rabbits retina, was taken by colored picture before and after the intravenous injection of $0.9 \mathrm{ml} / \mathrm{kg}$ of $2.0 \%$ callopeptide solution. (Fig. $4 \mathrm{~B}$ and C)

2. Blood pressure of carotid artery of rabbits.

normal-150-160 $\mathrm{mmHg}, 20 \mathrm{mmHg}$ lowering after the peritoneal injection of 1-2 $\mathrm{ml} / \mathrm{kg}$ of $1.0 \%$ solution of callopeptide (C.P)

Any more lowering of the blood pressure was not seen up to the lethal dose.

The evidence that the callopeptide belongs to the group of hypotensive tissue hormones in Table 1, would be made quite definite, by the comparison of physiological actions with that of bradykinin, as shown in Table 10.

Table 10

Comparison of Physiological Actions between Bradykinin and Callopeptide

\begin{tabular}{lccl}
\hline \multicolumn{1}{c}{ Action } & Bradykinin & Callopeptide \\
\hline $\begin{array}{l}\text { Hypotesnsive action } \\
\text { Contraction of visceral } \\
\text { smooth muscle }\end{array}$ & strong & medium & \\
$\begin{array}{l}\text { Dilatation of vascular } \\
\text { smooth muscle }\end{array}$ & + & slight & (Cat, \\
$\begin{array}{l}\text { Permeability of } \\
\text { capillary }\end{array}$ & with some controversies & + & Rat) \\
& increase & increase & \\
\hline Pain producing action & severe pain & severe pain & (Human) \\
\hline
\end{tabular}

Hypotensive action of both substances is different, it is strong in bradykinin and weak in callopeptide. Action to produce contraction for visceral smooth muscle is also strong in bradykinin, but it is very weak in callopeptide. Action of dilatation of vascular smooth muscle is strong but instant in bradykinin, on the contrary it is as well strong in callopeptide and it continued rather constant and for several hours. Still more the dilatatory action of vascular muscle due to bradykinin is much controversial. Some authors believe that bradykinin makes vein contraction, and its necessarily sequence the calillaries will be filled by blood, accordingly small arteries will be secondarily dilated. 6,13 But in callopeptide it seems to make arterioles, as well as venules dilate, consequently blood flow increases, first locally in the applied area and second in the peripheral vessels of the whole body. 
The last problem was a disclosure that bradykinin could not be absorbed through the rabbit's skin, but callopeptide will be absorbed. Table 11 shows that the threshold dose of callopeptide to dilate the blood vessels of mesentery examined by the abdominal window method was $0.06-0.08 \mathrm{mg} / \mathrm{kg}$ for a $2.5 \mathrm{~kg}$ rabbit. The dose was calculated as $0.006-0.008 \mathrm{mg} \%$ for the rabbit's body. When an area of $2 \times 20 \mathrm{~cm}$ was shaved in rabbit's both breast and coated by callopeptide containing cream of each $1 \mathrm{ml}$. The cream contained $0.07-0.11 \%$ callopeptide. In both sides, totally $1.4-2.2 \mathrm{mg}$ was used. Sixty to one hundred twenty minutes after paint, the blood vessels were dilated, in other words, through the skin the threshold amount to make dilatation was absorbed in the lapse of the

Table 11

Vasodilatory Action of Callopeptide through the Abdominal Window Method

\begin{tabular}{lcl}
\hline $\begin{array}{c}\text { Rabbit } \\
2.5 \mathrm{~kg}\end{array}$ & $\begin{array}{c}\text { Intravenously } \\
\text { appliction }\end{array}$ & $\begin{array}{l}\text { Application on skin } 2 \times 20 \mathrm{~cm} \\
\text { diameter areas in both breast }\end{array}$ \\
\hline $\begin{array}{l}\text { Threshold dose } \\
\text { of vasodilation }\end{array}$ & $0.06-0.08 \mathrm{mg}(\mathrm{pp}) / \mathrm{kg}$ & $\begin{array}{l}1.0 \mathrm{ml} \text { of } 0.07-0.11 \%(\mathrm{PP}) \text { in } \\
\text { dressing cream in both breast } \\
60-120 \mathrm{~min}\end{array}$ \\
$\begin{array}{l}\text { Latent period } \\
\begin{array}{l}\text { Calculated } \\
\text { concetration } \\
\text { Absorption rate }\end{array}\end{array}$ & $0.006-0.008 \mathrm{mg} \%$ & - \\
\hline
\end{tabular}

time. It must be calculated as $0.006-0.008 \mathrm{mg} \%$. In the skin area, there were 1.4-2.2 $\mathrm{mg}$ callopeptide, of which $4.28-5.7 \%$ amount was absorbed.

Thus the absorption rate of callopeptide through hair shaved skin area of $4 \times 20 \mathrm{~cm}$ of a rabbit has been obtained, and it is shown in next section, by another example in human by clinical application.

\section{A Few Trials of Clinical Application}

We confirmed first that callopeptide had no action to promote nor inhibit the cancer cell proliferation. The experiment was carried out with mice (dd $\mathrm{N}$ strain) in which cancer cells S-180 was transplanted into peritoneal cavity and the amount of $1.0 \mathrm{ml}$ of $10 \%$ callopeptide per $\mathrm{kg}$ was daily injected for 5 days in the experimental mice group. Along for 2 weeks in the control group as well as in the experimental group, the weight increase were quite same and all died in the same day. This was the preliminary base for the elinical application.

CASE 1. A 65 years old Japanese male was hospitalized on April 4, 1966, for complaint of pain in his legs for several months. A physician in charge, diagnosed neuralgia ischiadica with diabetes mellitus and cataracts. The disease 
are very popular in Japan and this was a typical one.

Immediately after hospitalization, Vitamin $B_{1}$ and aspirin and several times injection of narcotics a day were given to prevent the acute pain. And after 5 months of without success the doctor tried to use an ointment made by himself, which contained $1.0 \%$ of callopeptide (PP) to let the patient to paint at his both loan to legs expanding the medicament of about $5 \mathrm{ml}$, two times a day. To his surprise the pain of legs disappeared within 2 days and continued for next 6 hours. Third day, by the earnest beg of the patient, he gave the same treatment, and noticed that the warmfeeling taking the place of pain, in the lapse of $20-30$ min, and it continued for $6-7$ hours.

The treatment was fixed hereafter to give the ointment every 6 hours, and the patient was treated in such a way for 4 weeks, and it was without pain, and without sleeplessness. The doctor stopped the treatment and without any suggestion he painted the same looking ointment without callopeptide. The patient complained to doctor for a weak pain next day. After 3 days the patient felt severe pain in his legs and the doctor again treated him with callopeptide for 2 weeks. Two to three repetitions of such a procedure, the patients said that he had pain in these intermittent days, but gradually the pain has become weak and the different endurable one. The treatment is now continued as in Table 12.

Täble 12

Clinical Cases treated by Callopeptide

\begin{tabular}{|c|c|c|c|c|}
\hline $\begin{array}{l}\text { Cases } \\
\text { sex, age }\end{array}$ & Symptoms & Diagnosis & Treatment & Result \\
\hline $\begin{array}{l}\text { Case } 1 \\
\text { male } 56\end{array}$ & $\begin{array}{l}\text { pain attacks } \\
\text { in legs }\end{array}$ & $\begin{array}{l}\text { neuralgia icshia- } \\
\text { dica with } \\
\text { diabetes mellitus }\end{array}$ & $\begin{array}{l}3 \text { days } \\
\text { pain disapperaed }\end{array}$ & $\begin{array}{l}8 \text { weeks, weak } \\
\text { pain without } \\
\text { callopeptide }\end{array}$ \\
\hline $\begin{array}{l}\text { Case } 2 \\
\text { female } 47\end{array}$ & $\begin{array}{l}\text { severe pain } \\
\text { in left thigh } \\
\text { and left leg }\end{array}$ & $\begin{array}{l}\text { neuralgia icshia- } \\
\text { dica with spondylo- } \\
\text { lysis deformans }\end{array}$ & $\begin{array}{l}2 \text { days } \\
\text { pain disappeared }\end{array}$ & $\begin{array}{l}8 \text { weeks, pain is } \\
\text { remained in left } \\
\text { sole }\end{array}$ \\
\hline $\begin{array}{l}\text { Case } 3 \\
\text { male } 34\end{array}$ & $\begin{array}{l}\text { severe pain in } \\
\text { right shoulder } \\
\text { and right arm }\end{array}$ & $\begin{array}{l}\text { periarthritis } \\
\text { humeroscapularis } \\
\text { (Dupley's disease) }\end{array}$ & $\begin{array}{l}2 \text { days } \\
\text { pain disappeared }\end{array}$ & $\begin{array}{l}8 \text { weeks, com- } \\
\text { pletely recovered }\end{array}$ \\
\hline
\end{tabular}

CASE 2. 48 years old female, complained pain of left tigh and leg and was hospitalized at May 13th 1966. The physician in charge diagnosed spondylolysis deformans (osteoarthritis) with neuralgia ishiadica, on the base of Röntgen examination. Till October, all trials were done to inhibit pain without success, the doctor at last applied $1.0 \%$ callopeptide to paint the leg from the groin to the foot with $5 \mathrm{ml}$ of the ointment. The patient felt very warm within 
$20 \mathrm{~min}$. And the pain disappeared after 2 days. She was lame in the left leg since a year, but now she could walk without lame after two weeks callopeptide treatment. Amount of the ointment was reduced to half dose recently, but she had no pain for $6-7$ hours after the paint.

The intermittent period between treatments was made longer, at first 2 days between 2 weeks, then 4 days to 6 days. The pain of these days became endurable, till the end of 6 days, some severness returned. The beggining of December 1966, the pain was quite disappeared, except at her foot sole of the left leg, localised in about $5 \mathrm{~cm} \times 3 \mathrm{~cm}$.

CASE 3. 34 years old male patient, the diagnosis was periarthritis humeroscapularis (Duplay's disease). The pain attacks precipitated several times a day, and he visited the hospital in the end of September 1966. One month trials of various treatment, the doctor prescribed callopeptide, to paste it through shoulder of right side to the arm with $4 \mathrm{ml}$ a time, two times every day. At first the pain did not disappear till the third day (about 50 hours). But the pain has faded away gradually a step by step and the third day evening the patient found that he did not feel pain in his arm. All treatments hitherto tried were given up and the treatment continued 4 weeks, and stopped. The pain returned after 12 hours, but the patient felt a quite weak, and in a short time all pains disappeared. The treatment now discontinued for one month.

\section{Discussions and Prospects}

Summarization of the above study has been already discussed in section 4 . We have left many problems to be further studied, which were enumerated in Table 13.

The purification must be repeated, first to confirm the $N$ terminal at the same time C terminal of the callopeptide, but the ultimate structure is only to be

Table 13

Consequential Presumptions to be studied

1. The further analysis of the purified product.

2. The synthesis and identification.

3. In what species of animal besides Fur Seal does it naturally occur?

4. The further studies of its physiology.

1) Relation between bleeding and vasodilatation due to callopeptide.

2) Callopeptide and catecholamins.

3) Callopeptide upon blood clotting.

4) Callopeptide and plasmin or antiplasmin.

5. The further studies of clinical applications. 
attained by identification through a contrivable synthesis.

In one hand the further studies from the standpoint of physiology must be carried out and solve several problems, for example, whether the bleeding after a long surgical manipulation can be seen also in other areas, and its relation to vasodilatation due to callopeptide. Any effect does have callopeptide upon the blood clothing, or on the thrombus dissolution by plasmin. Are there antivasoactive substance contra callopeptides? Concerning to it action of cathecolamin on dilatation due to the callopeptide must be elucidated.

Table 14

Episodic Experiences remained to be Studied

A. External applications for

1) Writer's cramp. Occupational Raynaud's syndromes

2) Raynaud's disease-Gangrene

3) Neuritis due to metabolites

4) Rheumatoids

5) Skin diseases

(1) Acne

(2) Freckles

(3) Aged flecks of face

(4) Grey hair turns black

(5) Stop of baldness

(6) Keloid

(7) Eczema

6) Skin culture-cosmetic application

B. Internal applications for

1) Fatigue

2) Sleeplessness

3) Renewal of vitality

The biological importance, is in the question, in what species of animal besides fur seals does the callopeptide naturally occur? Because we could not believe that the substance is contained in fur seals muscles only.

The further studies of clinical applications must be extended to several diseases as in Table 13, from the principle that the local vasodilative action can reinforce tissue activities, among them, to Raynoud's disease, including occupational Raynoud's syndrome and writer's cramp which deserve to try by the external use of the substance.

There have been episodical experiences in our surroundings as shown in Table 14, but these must be experimentally elucidated. First, by the external application of the substance on skin diseases, for example 1) acne 2) keloid and 
3) some eczema. Second, also the external application is for skin culture. Exploitation of callopeptide containing dressing creams for cosmetic use already has been progressed in Japan since 2 years. If it might be absorbed through alimentory canal up to some grade without decomposition, as it is absorbed through skin (Table 11), we can apply it to cure general fatigue or sleeplessness.

\section{ACKNOWLEDGMENTS}

The authors are highly indebted to Dr. Taneko Suzuki, Tokai Regional Fisheries Research Laboratory, Fisheries Agency, Japanese Government, for her help to accomplish the extraction method with the material disposed of by Japanese Government, and to Dr. Masaharu Nishiwaki, Professor of Marine Biology, Ocean Research Institute, University of Tokyo, for his help to confirm the material biologically.

\section{REFERENCES}

1. Beraldo, W. T.: Am. J. Physiol. 171: 371, 1952.

2. Bhoola, K. D., Calle, J. D. and Schachter, M.: J. Physiol (London) 151: 35, 1960.

3. Erspamer, V., Bertaccini, G. and Gei, J. M.: Experientia 18: 562, 1962.

4. Erspamer, V.: Arzneimittel-Forsch 2: 253, 1952.

5. von Euler, U. S. and Gaddum, J. H.: Z. Physiol. Chem. 72: 74, 1931.

6. Guth, P. S., Robbin, G., Cano, G. and Amaro, J.: Venocontraction induced by bradykinin in the rabbit ear. In "Hypotensive peptide" ed. Erdös, E. G., Back, N. and Sicuteri, F., Springer-Verlag, New York, 1966.

7. Jaques, R. and Schachter, M.: Brit. J. Pharmacol. 2: 53, 1954 ,

8. Rocha e Silva, M., Beraldo, W. T. and Rosenfeld, G.: Am. J. Physiol. 156: 261, 1949.

9. Schachter, M.: "Polypeptides which affect smooth muscles and blood vessels," Pergamon Press, London, 1960.

10. Scheffer, V. B.: "Seals, Sea lions and walruses. A Review of the Pinnipedia," Stanford University Press, Oxford University Press, 1958.

11. Schröder, E. and Lübke, K.: "The Peptide" translated by Gross, E. Vol. I and II, Academic Press, New York and London, 1965 \& 1966.

12. Schwyzer, R.: Chimia (Aaru) 12: 58, 1958.

13. Shimamoto, T., Numano, F., Fujita, T., Ishioka, T. and Atsumi, T.: Treatment of experimental and human atherosclerosis with bradykinin antagonist. in "Hypotensive Peptides" ed. Erdös, E. C., Back, N. and Sicuteri, F., See this references, 6. 1966.

14. Werle, E. in polypeptides which affect Smooth Muscle and blecd vessels. (M. Schachter ed.) See this references, 9: 1960.

15. Werle, E. and Erdös, E. G.: Arch. Exptl. Pathol. Pharmeol. 223: 224, 1954. 